\title{
The Exploration Into the Innovation Strategies of Badminton Teaching in Modern Universities
}

\author{
Xiong Xiang ${ }^{1, *}$ Hanwei Lee ${ }^{2}$ \\ ${ }^{1}$ Wuhan Railway Vocational College of Technology, Wuhan, Hubei, China \\ ${ }^{2}$ University of Sydney, Sydney, Australia \\ *Corresponding author. Email: tomgegeshiwo@163.com
}

\begin{abstract}
In recent years, many universities in China have set up badminton elective courses, in response to the national quality education requirements. However, in the real teaching setting, many universities have followed the traditional teaching ideas and teaching modes, seriously hindering the overall quality of college students in modern universities. The thesis expounds the necessity of developing badminton teaching in Chinese colleges and universities, analyzes the problems in college badminton teaching, and puts forward the innovative measures of college badminton teaching in terms of teaching concept, teaching method and teaching mode. It provides a scheme for effectively solving the shortcomings in college badminton teaching.
\end{abstract}

Keywords: Innovation strategies, Badminton teaching, Modern universities.

\section{INTRODUCTION}

As a very popular sport, badminton with its special charm, elegant way in the world has a very high visibility. Badminton requires fast ball speed, varied moves and high response ability of players in the process of fighting. In recent years, badminton, as an elective physical education course in colleges and universities, has been favored by college students and gradually plays an indispensable role. However, in the teaching of badminton, there are many unsatisfactory places, some colleges and universities even fail to recognize the teaching purpose of badminton, in the teaching process, blindly pursue competition, seriously deviated from the original intention of introducing badminton in the physical education teaching. In order to promote the reform of physical education in colleges and universities, this paper elaborates the necessity of badminton teaching in colleges and universities and relevant innovative countermeasures.

\section{THE NECESSITY OF BADMINTON TEACHING IN COLLEGES AND UNIVERSITIES}

\subsection{The Requirements of the National Guidelines for Physical Education Course Teaching in Regular Institutions of Higher Learning}

In recent years, with the gradual implementation of the concept of quality-oriented education, the Ministry of Education of China recently formulated the "National Physical Education Curriculum Guidance Outline", which not only redefined the nature of physical education in colleges and universities, but also put forward the idea of people-oriented education and advocated the importance of the development of students' personality. In addition, the outline also makes clear the teaching achievement evaluation method of college physical education teachers, the scoring criterion and so on, and formulates the teaching quality measurement basis of various college sports items. In the course of badminton teaching in colleges and universities, it is necessary to strictly refer to the Guidance Outline of Physical Education Course in National Colleges and Universities, and practice the teaching requirements of the state to 
improve the comprehensive quality of college students.

\subsection{The Need to Improve the Badminton Skill Level}

After students enter the university, it means that they are about to enter the society and face fierce competition. By playing badminton competition, they can significantly strengthen their competitive consciousness and improve their competitive ability. Therefore, in the process of badminton learning, college students should improve their personal sports skills in a targeted way. Specifically, it is necessary to grasp the changes of the environment in real time in the badminton course, and constantly display the charm of badminton through self-adjustment. Based on this demand, badminton teaching in colleges and universities should promote students' physical and psychological improvement through various technical teaching. It can be said that when students obtain the improvement of their technical level, they can also help to realize the affirmation of their personal value and improve their confidence in life.

\subsection{Developing Good Exercise Habits and Improving Physical Quality}

College badminton teaching, involves the teacher to student's sports theory teaching and teachers' interpretation of various kinds of sports skills, through the study of the theory of all kinds of sports, not only can help students to reduce the occurrence of all kinds of risk in the process of movement, still can make students feel the fun of sports, to develop good exercise habits. College students in the 21 st century should be all-round talents with moral, intellectual, physical, aesthetic and labor qualities, among which, a healthy physical quality is the basis for other activities. In the future, it is believed that by forming good sports habits, students can not only improve their personal physical quality, but also help college students to form a positive life attitude and correct life values. Of course, this is also one of the most important significance of badminton teaching activities.

\section{PROBLEMS IN BADMINTON TEACHING IN COLLEGES AND UNIVERSITIES}

At present, the physical condition and health of college students are not optimistic, which to some extent reflects the problem that the current physical education in colleges is not ideal. With the quickening of social development and the deepening of international communication, how to find a way to adapt to The Times and how to make students establish a correct concept of sports through physical education are the problems that colleges and universities need to consider. As far as the current mode of badminton teaching in colleges and universities is concerned, it is far from meeting the needs of quality-oriented education, and some disadvantages have even seriously restricted the allround development of college students.

\subsection{The Course Content Is Monotonous}

In badminton teaching, it is often necessary to repeat a certain action, and the course content is relatively monotonous. Sometimes the course content becomes the training hours of competitive events, which is easy to make students hate, which has a serious blow to the enthusiasm of students in class.

\subsection{The Initial Level of Students Is Different}

College students came from all directions, the student original badminton technology good and bad are intermingled, and college teachers often take "many years" teaching methods, this leads to hard to consider the needs of all students in the teaching process, is not conducive to students at all levels of badminton technology to improve, to meet the need of exercise intensity.

\subsection{The Assessment Method Is Monotonous and Boring}

Badminton examination is an indispensable link in the badminton teaching, although it prompted students exercise intensity increased to some extent, but the neglect of students' learning attitude appraisal way many incompetent or seriously affected the student's enthusiasm, this kind of no distinction between the way of teaching is one of the largest disadvantages restrict the development of Chinese physical education. 


\section{INNOVATION MEASURES OF BADMINTON TEACHING IN UNIVERSITIES}

\subsection{Innovating the Concept of Badminton Teaching}

Physical education should be guided by qualityoriented education and centered on cultivating students' ability to exercise, study and create independently. In the teaching of badminton course, the key is to highlight its entertainment. Teachers should take teaching tasks, students' ability and course characteristics into consideration, and put forward various teaching methods creatively in the teaching process, so as to achieve the classroom effect that teachers can teach easily and students can learn happily. According to the research of psychologists, in the process of learning, the most important factor that affects the quality and efficiency of learning is the awareness of interest in the learning content. In other words, students can grasp what they have received more firmly in a state of high interest. Therefore, in the process of physical education, we should pay attention to guide education, pay attention to stimulate and deepen students' interest and hobby in badminton, so that students can experience the happiness of badminton in sports, stimulate students' initiative and consciousness in learning badminton, and form a good habit of lifelong exercise.

According to the relevant research, in the evaluation of students' sports performance, if the comprehensive consideration of the degree of technical improvement, learning attitude and other situations, and effectively let the students get the actual evaluation, can encourage students to produce new goals and motivation, and through efforts to achieve success. Therefore, colleges and universities in the badminton teaching process, the key is to consider the students' participation, through a variety of guide mechanism, evaluation feedback mechanism continuously stimulate students with full enthusiasm to participate in the curriculum, eliminates the athletic psychology, and led by the demands of entertainment, relieve the anxiety of students' test, let each student after the effort, to be able to easily through the examination.

\subsection{Innovating Badminton Teaching Methods}

\subsubsection{Experiential Teaching of Badminton}

The so-called experiential teaching means that in the process of badminton teaching, students are designed from five aspects of sense, emotion, thinking, action and association, so as to achieve good emotional, intellectual and physical experience. In actual teaching, the teacher can make full use of sensory experience of students, stimulate the students' sensory understanding, in the teaching of the action, for example, can be in the first place to teach some students interested in action, such as to kill the ball, the back technology, to the largest extent, causes the student to obtain good sensory experience, then next badminton course full of interest.

In addition to the sensory experience, there is a personal experience. In the process of teaching detailed badminton movements, teachers can design teaching activities for a certain combination of movements to help each student get his or her own unique perception in the actual experience. For some students' personalized actions, they can be properly corrected, but not completely banned. Students should be encouraged to make innovations in practical activities. Only in this way can students acquire more personalized perception and understanding of badminton, life and development of things.

\subsubsection{Carrying out Badminton Interactive Teaching}

In traditional teaching methods, the subjectobject relationship between teachers and students is very clear. Teachers are responsible for teaching, students are responsible for listening, and there is no necessary interaction between teachers and students. The interactive teaching mode requires the teacher as the organizer and instructor of teaching activities, fully pay attention to the main position of students in learning, try to create a democratic, relaxed, happy learning environment for students, with the pleasure of teaching, so that students can obtain knowledge and skills in a relaxed and pleasant.

For example, when teachers teach badminton skills in colleges and universities, students with strong sports skills can hit the ball with the left hand that they are not good at to balance the strength of both sides. The whole exercise process 
is filled with laughter. The students with stronger skills can train their reaction ability, while the students with less skills can gain confidence, thus better promoting the improvement of both students' technical level.

\subsubsection{Using Multimedia and Other Modern Teaching Means to Teach}

The textbook mainly spreads theoretical knowledge through words, maps and CD-ROM, and there are more than 40 basic skills of badminton, so it is impossible to cover all aspects in the textbook, so multimedia teaching should be introduced in the actual teaching process. As a product of the development of modern science and technology, multimedia can help students to observe various badminton moves more carefully, stimulate students' perceptual system, and urge them to study the changing rules of various movements deeply. The biggest advantage of multimedia teaching is to be able to achieve accurate reproduction of movements, for some complex movements, but also for slow motion playback. At the same time, in the process of organizing students to watch the badminton video, teachers can simultaneously explain the various video movements and tactics presented in the video, and then simply summarize the key technical points in the game, so that students can deepen their understanding of various technical movements with high interest.

\subsubsection{Paying Attention to the Organization of High Level Badminton Match, Teaching Match Combination}

High-level badminton matches can enable students to fully appreciate the charm of badminton in the process of participating in the game and watching the game, and create a stage for students who work hard to show their training achievements. However, the differences between the badminton levels of colleges and universities must be fully taken into account when setting up the matches. If necessary, different levels of matches can be set according to different levels of levels, which can not only enhance the wonderful degree of the matches, but also improve the interest of the sports teams of colleges and universities with lower levels. With the improvement of badminton skills of college teams, when conditions are ripe, they can imitate some league matches and hold national badminton matches.
In addition, in the teaching process to join the competition link, can mobilize students' learning enthusiasm, active classroom atmosphere. The teacher teaches some sports skills, techniques and tactics, rules and refereeing, and lets the students organize their own competitions.

\subsection{Innovating Badminton Teaching Mode}

\subsubsection{Creating the Teaching Situation of "Situational Analysis"}

This teaching mode requires teachers to prepare well before class and students to prepare well before class. In the course of badminton teaching, students' pre-class preview can promote students to have a certain understanding of the skills they have learned in a rational way. Before the teaching demonstration, the teacher should explain the key points and difficulties of the movement techniques to be taught carefully, and ask the students to observe the demonstration movements carefully. Finally, in the process of teaching practice, teachers can adopt interesting teaching and create a teaching situation of situation analysis, such as imitating a series of classic technical movements of today's elite badminton players, so as to attract students' attention and stimulate their interest in learning.

\subsubsection{Creating the Teaching Scene of "Emotional Innovation"}

The ability of innovation is very important for a person's development. It can not only stimulate people's desire for knowledge, but also make people's spirit happy and enhance their interest in things. In badminton teaching in colleges and universities, teachers should pay attention to cultivating students' ability to design and organize exercises of sports skills independently, encourage students to think divergently, practice boldly and innovate bravely, and improve their ability to solve problems independently. Students can practice according to the practice form and method provided by the teacher, or design the practice form and method independently according to their own reality. The teaching situation of "emotional innovation" is that teachers and students cooperate closely, communicate with each other, and jointly find out a badminton teaching program suitable for each student's own development. 


\section{CONCLUSION}

In a word, in the process of badminton teaching, colleges and universities must give full consideration to the physical and mental characteristics of college students, and ensure that the teaching methods are interesting and healthy while carrying out theoretical teaching, so as to ensure that the competitive and comprehensive physical education in colleges and universities can be reflected. As a sport dominated by skills, badminton's skill level determines its sport level. What colleges and universities need to think about in badminton teaching is how to help students improve their sports efficiency, develop good sports habits, and how to make reasonable use of training resources. In the future, we believe that as long as we combine all kinds of innovative ideas and countermeasures, we will be able to effectively solve the disadvantages of badminton teaching in colleges and universities.

\section{AUTHORS' CONTRIBUTIONS}

This thesis is completed by Xiong Xiang and Hanwei Lee. Xiong Xiang wrote the manuscript, and Hanwei Lee is responsible for revising.

\section{REFERENCES}

[1] Wang Ruiyuan. Exercise Physiology [M]. Beijing: People's Sports Publishing House, 2002:244-248.

[2] Zhang Lunhou. Reform and Practice of Tennis Teaching Mode in Colleges and Universities [J]. Journal of Jilin Institute of Physical Education, 2003 (4): 67-68.

[3] Zhong Da. "One Key" and "Four Basis" in Badminton Teaching[J]. Physical Education, 2005 (1): 24-25.

[4] Yu Xiang. Research and Experiment on Teaching Methods of Badminton Elective Course [J]. Journal of Jilin Physical Education University, 2005 (3) : 38.

[5] Ye Qing. Research on the teaching of badminton optional course in colleges and universities [J]. Journal of Hefei University of Technology: Social Science Edition, 2007 (2) : 175-178.

[6] Ouyang Weibing, Tang Shaolin, Problems and Suggestions on Badminton Teaching in
Schools $[\mathrm{J}]$. Contemporary Sports Technology, 2020(36) p108-112. 